\title{
Central Daylight Time
}

National Cancer Institute

\section{Source}

National Cancer Institute. Central Daylight Time. NCI Thesaurus. Code C116258.

Local daylight-savings time, based at the 90th meridian west of the Greenwich

Observatory, established as five hours behind Coordinated Universal T ime. 